\title{
Luc Bonenfant, Nom propre, poésie et généricité: Bertrand, Rimbaud
}

\section{Chiara Lanciano}

\section{(2) OpenEdition}

1 Journals

\section{Édition électronique}

URL : http://journals.openedition.org/studifrancesi/9623

DOI : 10.4000/studifrancesi.9623

ISSN : 2421-5856

Éditeur

Rosenberg \& Sellier

\section{Édition imprimée}

Date de publication : 1 décembre 2007

Pagination : 687

ISSN : 0039-2944

\section{Référence électronique}

Chiara Lanciano, «Luc Bonenfant, Nom propre, poésie et généricité: Bertrand, Rimbaud », Studi Francesi [En ligne], 153 (LI | III) | 2007, mis en ligne le 30 novembre 2015, consulté le 11 janvier 2021. URL http://journals.openedition.org/studifrancesi/9623 ; DOI : https://doi.org/10.4000/studifrancesi.9623

Ce document a été généré automatiquement le 11 janvier 2021.

\section{(c) (i) (9)}

Studi Francesi è distribuita con Licenza Creative Commons Attribuzione - Non commerciale - Non opere derivate 4.0 Internazionale. 


\title{
Luc Bonenfant, Nom propre, poésie et généricité: Bertrand, Rimbaud
}

\author{
Chiara Lanciano
}

\section{RÉFÉRENCE}

LUC BONENFANT, Nom propre, poésie et généricité: Bertrand, Rimbaud, Verhaeren, «French studies», Oxford Journals, 4 October 2006, pp. 453-465.

1 Peut-on parler de «différenciation générique» quand il s'agit d'attribuer un nom à un personnage?

2 À travers l'étude de poésies d'Aloysius Bertrand, l'A., dans une première partie, analyse le fonctionnement générique du Nom. Celui-ci peut avoir une fonction narrative, s'il agit en tant que déictique textuel et anticipe l'évolution du récit tel qu'on le trouve dans la narration romanesque. Le Nom peut aussi avoir une fonction sémantique ou poétique, jouant par exemple sur les sonorités: il dépasse sa simple fonction référentielle et acquiert ainsi une dimension plus vaste, voire totalisante, qui distingue la poésie des autres genres.

3 Dans une seconde partie l'A. souligne le fait que la poésie est avant tout un genre à faible densité onomastique contrairement au roman et s'intéresse de plus près, à travers l'analyse détaillée des Noms dans la poésie de Rimbaud et de Verhaeren, au cas de la poésie en prose qui, grâce à sa «souplesse formelle» apparaît comme «l'espace de transition générique par excellence». 